Article

\title{
Genome-Wide Characterization of NBS-Encoding Genes in Watermelon and Their Potential Association with Gummy Stem Blight Resistance
}

\author{
Md Zahid Hassan ${ }^{\mathbb{D}}$, Md Abdur Rahim ${ }^{\mathbb{D}}$, Hee-Jeong Jung, Jong-In Park, Hoy-Taek Kim and \\ Ill-Sup Nou *(D)
}

Department of Horticulture, Sunchon National University, Suncheon 57922, Korea; zhassan.pstu@gmail.com (M.Z.H.); rahimgepb@sau.edu.bd (M.A.R.); gml79wjd@scnu.ac.kr (H.-J.J.); jipark@sunchon.ac.kr (J.-I.P.); htkim@sunchon.ac.kr (H.-T.K.)

* Correspondence: nis@sunchon.ac.kr; Tel.: +82-61-750-3249

Received: 3 January 2019; Accepted: 17 February 2019; Published: 19 February 2019

\begin{abstract}
Watermelon (Citrullus lanatus) is a nutritionally rich and economically important horticultural crop of the Cucurbitaceae family. Gummy stem blight (GSB) is a major disease of watermelon, which is caused by the fungus Didymella bryoniae, and results in substantial economic losses in terms of yield and quality. However, only a few molecular studies have focused on GSB resistance in watermelon. Nucleotide binding site (NBS)-encoding resistance $(R)$ genes play important roles in plant defense responses to several pathogens, but little is known about the role of NBS-encoding genes in disease resistance in watermelon. The analyzed NBS-encoding $R$ genes comprises several domains, including Toll/interleukin-1 receptor(TIR), NBS, leucine-rich repeat (LRR), resistance to powdery mildew8(RPW8) and coiled coil (CC), which are known to be involved in disease resistance. We determined the expression patterns of these $R$ genes in resistant and susceptible watermelon lines at different time points after $D$. bryoniae infection by quantitative RT-PCR. The $R$ genes exhibited various expression patterns in the resistant watermelon compared to the susceptible watermelon. Only six $R$ genes exhibited consistent expression patterns (Cla001821, Cla019863, Cla020705, Cla012430, Cla012433 and Cla012439), which were higher in the resistant line compared to the susceptible line. Our study provides fundamental insights into the NBS-LRR gene family in watermelon in response to D. bryoniae infection. Further functional studies of these six candidate resistance genes should help to advance breeding programs aimed at improving disease resistance in watermelons.
\end{abstract}

Keywords: gummy stem blight; watermelon; resistance; NBS genes; expression

\section{Introduction}

Watermelon (Citrullus lanatus) is one of the most important cucurbit crops worldwide. This crop is well known in all tropical and subtropical regions of the world, where it is primarily grown for the fresh consumption of the juicy, sweet flesh of its mature fruit [1]. Watermelon plays a significant role in human health by providing important nutritional compounds, such as sugars and lycopene, and cardiovascular health-promoting amino acids, including arginine, glutathione and citrulline [2].

However, watermelon is frequently affected by several pathogens and insects, including fungi, bacteria, viruses and aphids. Gummy stem blight (GSB) is one of the most destructive diseases of watermelons. GSB is caused by the soil, seed and airborne fungus Didymella bryoniae [3,4]. This disease also affects other cucurbit crops, including melon, cucumber and squash $[5,6]$. GSB in watermelon causes crown blight, stem cankers and extensive defoliation, with symptoms detected in cotyledons, 
hypocotyls, leaves and fruits. This results in severe economic losses in the field and fruit losses during storage [4,7]. It is difficult to properly control GSB using chemical methods and the frequent use of fungicides is not desirable due to their negative impact on the environment $[4,8]$. Consequently, developing GSB-resistant watermelon cultivars containing major resistance genes through gene pyramiding represents the most environmentally sustainable and economically viable means of GSB management $[4,9]$.

Due to the agricultural importance of this disease, early studies have focused on identifying the sources of genetic resistance to GSB [10]. However, few such sources have been reported in watermelon $[4,7]$. The identification of linked markers is essential for exploring GSB resistance in watermelon genotypes from diverse germplasm. However, no molecular studies of GSB resistance in watermelon have thus far been reported and current efforts are still focused on developing a GSB-resistant watermelon cultivar.

Resistance $(R)$ genes play important roles in plant immune systems in response to various pathogens and insects, including viruses, bacteria, fungi, aphids and nematodes [11]. Disease resistance in plants involves the interaction between the avirulence (avr) genes of the pathogen and specific disease resistance $(R)$ genes of plants, with such interactions described by the gene-for-gene model [12,13]. This form of plant resistance can be lost due to the development of new races of pathogens via evolution or as a consequence of the evolutionary loss of $R$ genes [14].

Most $R$ genes in plants encode proteins that are comprised of a nucleotide-binding site (NBS) and leucine-rich repeats (LRRs), which play vital roles in plant-pathogen recognition [15]. The NBS domains, which bind to and hydrolyze adenosine triphosphate (ATP) or guanosine triphosphate (GTP), are involved in signaling, whereas LRRs are highly adaptable structural domains that are responsible for protein-protein interactions [15]. Plant NBS-LRR proteins can be classified into two subgroups based on the identity of the sequences that precede the NBS domain: TIR-NBS-LRR (TNL) proteins that have Toll-like domains and CC-NBS-LRR (CNL) proteins that are characterized by their coiled-coil domains. Watermelon contains 44 NBS-LRR genes, as revealed by genomic analysis [1]. $R$ genes have been identified in a number of plant species, including Arabidopsis thaliana [16], rice [17,18], melon [19], cucumber [20] and apple [21]. Initially, we identified GSB-resistant watermelon lines through an extensive bioassay. Since NBS-encoding $R$ genes have been reported to confer resistance against various pathogens and insects in different plant species, the $R$ genes were explored in watermelon. Further, the availability of the complete genome sequences of $C$. lanatus allowed us to systematically analyze the NBS-encoding $R$ genes in watermelon.

However, little is known about NBS-encoding $R$ genes in resistant and susceptible watermelon lines/cultivars. Therefore, in this study, we analyzed the expression patterns of NBS-encoding genes in $D$. bryoniae-resistant and -susceptible watermelon lines to identify candidate $R$ genes conferring resistance to GSB, which could be highly useful for breeding programs.

\section{Results}

\subsection{Distribution of 44 NBS-Encoding Genes in Watermelon Chromosomes}

A total of 44 NBS-encoding $R$ genes were previously identified in the watermelon genome [1]. In this study, we found that the genes are differentially expressed in susceptible compared to resistant $C$. lanatus lines. Forty-four $R$ genes are distributed across nine $C$. lanatus chromosomes, ranging from 1 to 10 genes per chromosome (Figure 1, Table 1). The highest number of NBS-encoding genes was found on Chr2 (Cla006803, Cla006813, Cla006820, Cla019844, Cla019831, Cla019854, Cla019855, Cla019856, Cla019857 and Cla019863) and Chr8 (Cla001017, Cla012424, Cla012425, Cla012427, Cla012428, Cla012430, Cla012431, Cla012434 and Cla012439), whereas the lowest number was found on Chr0 (Cla000024). Chr1, Chr5, Chr9 and Chr11 each contain three NBS-encoding genes, while Chr7 contains five and Chr10 contains six genes (Figure 1). 


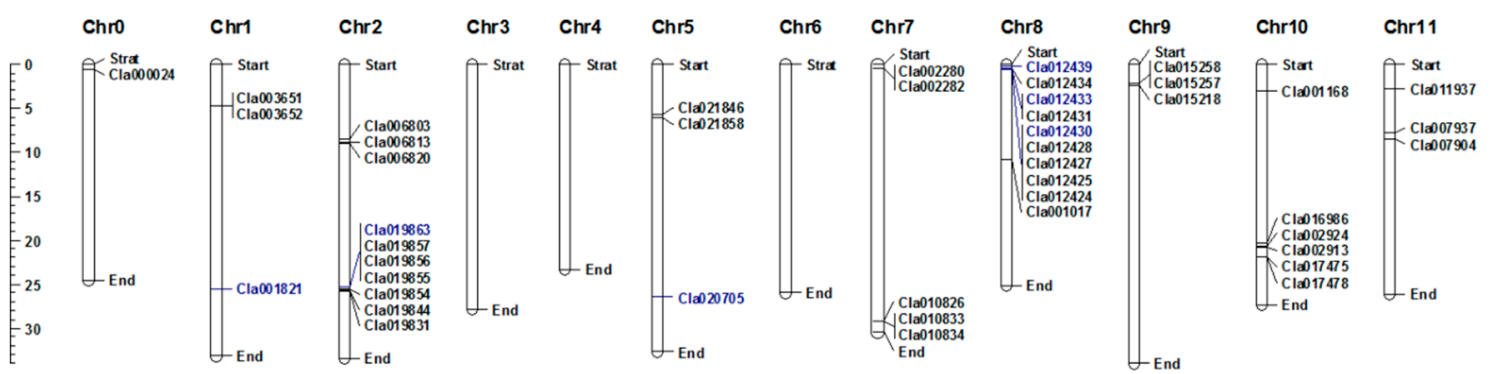

Figure 1. Distribution of the 44 NBS-encoding $R$ genes on the watermelon chromosomes. The genes shown in blue are the candidate NBS-encoding genes for gummy stem blight resistance in watermelon. The positions of genes on the watermelon chromosomes were drawn using MapChart software [22].

\subsection{Exon-Intron Structure}

To better understand the genomic structures of the 44 NBS-encoding $R$ genes, we generated exon-intron diagrams of the genes by comparing their coding sequences with the corresponding genomic sequences using the online tool GSDS2.0 (http://gsds.cbi.pku.edu.cn/). The number of exons per gene was 1-8 (Figure 2). The highest number of exons was found in Cla019855 and Cla021846, while the lowest was found in Cla001017, Cla006813, Cla012424, Cla003651,Cla003652, Cla006803, Cla002913, Cla006820, Cla010833, Cla010834, Cla015257, Cla017475, Cla017478 and Cla021858. Three genes (Cla007937, Cla011937 and Cla012428) contain six exons while three other genes (Cla012431, Cla019857 and Cla019863) contain seven exons. The number of introns per gene was 0-7. Cla019855 and Cla021846 contain the most introns, whereas 14 genes lack introns (Figure 2).

Table 1. Location of 44 NBS-encoding genes on the watermelon chromosomes.

\begin{tabular}{|c|c|c|c|c|c|c|}
\hline S1. No. & Gene Name ${ }^{a}$ & Chr & Start & End & CDS (bp) & Protein (aa) \\
\hline 1 & Cla000024 & Chr0 & 573,701 & 575,732 & 1725 & 574 \\
\hline 2 & Cla001821 & Chr1 & $26,529,719$ & $26,532,585$ & 2448 & 815 \\
\hline 3 & Cla003651 & Chr1 & $5,737,988$ & $5,740,048$ & 2061 & 686 \\
\hline 4 & Cla003652 & Chr1 & $5,741,726$ & $5,742,592$ & 867 & 288 \\
\hline 5 & Cla006803 & Chr2 & $9,631,689$ & $9,634,916$ & 3228 & 1075 \\
\hline 6 & Cla006813 & Chr2 & $9,860,817$ & $9,862,469$ & 1653 & 550 \\
\hline 7 & Cla006820 & Chr2 & $9,989,292$ & $9,992,234$ & 2943 & 980 \\
\hline 8 & Cla019831 & Chr2 & $26,750,001$ & $26,753,327$ & 2445 & 814 \\
\hline 9 & Cla019844 & Chr2 & $26,582,380$ & $26,589,679$ & 4227 & 1408 \\
\hline 10 & Cla019854 & Chr2 & $26,456,943$ & $26,459,976$ & 2667 & 888 \\
\hline 11 & Cla019855 & Chr2 & $26,449,200$ & $26,453,033$ & 2826 & 941 \\
\hline 12 & Cla019856 & Chr2 & $26,439,873$ & $26,444,126$ & 2832 & 943 \\
\hline 13 & Cla019857 & Chr2 & $26,432,098$ & $26,437,657$ & 3036 & 1011 \\
\hline 14 & Cla019863 & Chr2 & $26,383,499$ & $26,388,744$ & 3588 & 1195 \\
\hline 15 & Cla020705 & Chr5 & $27,501,959$ & $27,505,144$ & 2466 & 821 \\
\hline 16 & Cla021846 & Chr5 & $6,824,170$ & $6,829,020$ & 1239 & 412 \\
\hline 17 & Cla021858 & Chr5 & $6,953,920$ & $6,957,366$ & 3447 & 1148 \\
\hline 18 & Cla002280 & Chr7 & $1,370,278$ & $1,374,401$ & 3930 & 1309 \\
\hline 19 & Cla002282 & Chr7 & $1,381,169$ & $1,385,954$ & 2979 & 992 \\
\hline 20 & Cla010826 & Chr7 & $30,211,275$ & $30,212,050$ & 606 & 201 \\
\hline 21 & Cla010833 & Chr7 & $30,251,502$ & $30,254,738$ & 3237 & 1078 \\
\hline 22 & Cla010834 & Chr7 & $30,256,839$ & $30,260,099$ & 3261 & 1086 \\
\hline 23 & Cla001017 & Chr8 & $11,759,681$ & $11,762,959$ & 3279 & 1092 \\
\hline 24 & Cla012424 & Chr8 & $1,647,030$ & $1,648,988$ & 1377 & 458 \\
\hline 25 & Cla012425 & Chr8 & $1,641,639$ & $1,643,644$ & 1299 & 432 \\
\hline 26 & Cla012427 & Chr8 & $1,609,802$ & $1,613,337$ & 3042 & 1013 \\
\hline 27 & Cla012428 & Chr8 & $1,595,322$ & $1,601,397$ & 4353 & 1450 \\
\hline 28 & Cla012430 & Chr8 & $1,580,252$ & $1,584,048$ & 1278 & 425 \\
\hline 29 & Cla012431 & Chr8 & $1,547,018$ & $1,555,932$ & 4578 & 1525 \\
\hline 30 & Cla012433 & Chr8 & $1,530,729$ & $1,534,838$ & 2454 & 817 \\
\hline
\end{tabular}


Table 1. Cont.

\begin{tabular}{ccccccc}
\hline Sl. No. & Gene Name $^{\text {a }}$ & Chr & Start & End & CDS (bp) & Protein (aa) \\
\hline 31 & Cla012434 & Chr8 & $1,420,444$ & $1,427,949$ & 3423 & 1140 \\
32 & Cla012439 & Chr8 & $1,331,566$ & $1,335,184$ & 2469 & 822 \\
33 & Cla015218 & Chr9 & $3,429,200$ & $3,430,883$ & 1404 & 467 \\
34 & Cla015257 & Chr9 & $3,116,792$ & $3,119,902$ & 3111 & 1036 \\
35 & Cla015258 & Chr9 & $3,111,030$ & $3,115,364$ & 3444 & 3444 \\
36 & Cla001168 & Chr10 & $4,050,530$ & $4,052,711$ & 1050 & 349 \\
37 & Cla002913 & Chr10 & $21,882,174$ & $21,883,565$ & 1392 & 463 \\
38 & Cla002924 & Chr10 & $21,745,526$ & $21,748,738$ & 3213 & 1070 \\
39 & Cla016986 & Chr10 & $21,332,030$ & $21,336,749$ & 3402 & 1133 \\
40 & Cla017475 & Chr10 & $22,939,927$ & $22,942,518$ & 2592 & 863 \\
41 & Cla017478 & Chr10 & $22,955,431$ & $22,957,062$ & 1632 & 543 \\
42 & Cla007904 & Chr11 & $9,507,150$ & $9,514,341$ & 4062 & 1353 \\
43 & Cla007937 & Chr11 & $8,764,524$ & $8,779,874$ & 3391 & 1155 \\
44 & Cla011937 & Chr11 & $3,833,117$ & $3,836,951$ & 1725 & 574 \\
\hline
\end{tabular}

${ }^{a}$ Genomic information retrieved from the Cucurbit Genomics Database (http:/ / cucurbitgenomics.org) using 97103 as the reference genome for watermelon.

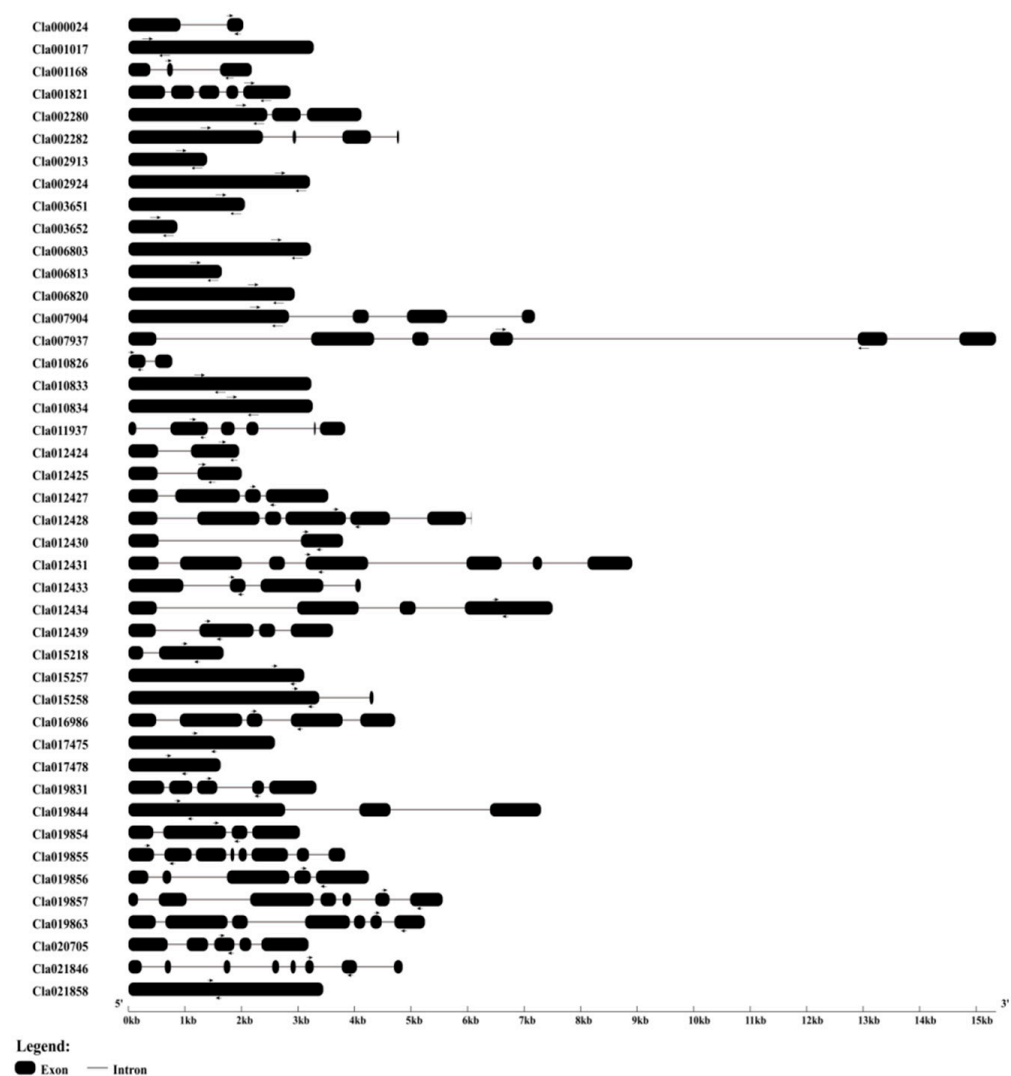

Figure 2. Exon-intron structures of the 44 NBS-encoding $R$ genes from watermelon. Rectangles and gray lines indicate exons and introns, respectively. Left and right arrows indicate position of forward and reverse primers, respectively.

\subsection{Conserved Domain and Motif Analysis}

We analyzed the conserved domains of the 44 NBS-encoding $R$ genes using the Conserved Domain Database (CDD) of NCBI and the Pfam protein database v30.0 (https:/ / www.ncbi.nlm.nih. gov/structure/cdd/wrpsb.cgi). These results are shown in Figure 3 and Table 2. All 44 proteins have a highly conserved NBS (NB-ARC) domain. The $R$ genes were grouped in different classes based on the presence of the following conserved domains: (i) NBS, (ii) NBS-LRR, (iii) LRR, (iv) RPW8-NBS-LRR, (v) TIR, (vi) TIR-LRR, (vii) CC-NBS and (viii) CC-NBS-LRR (Table 3). Three genes (Cla001821, Cla019831 and Cla020705) encode proteins with both RPW8 and NBS-LRR domains. We subjected the 44 NBS 
proteins to motif analysis using the MEME Suite (http:/ / meme-suite.org/tools/meme). These results are shown in Figure 4 and Table 4 . We detected 20 conserved motifs, each being comprised of over 13 amino acids. The greatest number of motifs was identified in the CC-NBS-LRR domain-containing gene Cla021858, whereas the fewest were detected in Cla001168 and Cla021846.

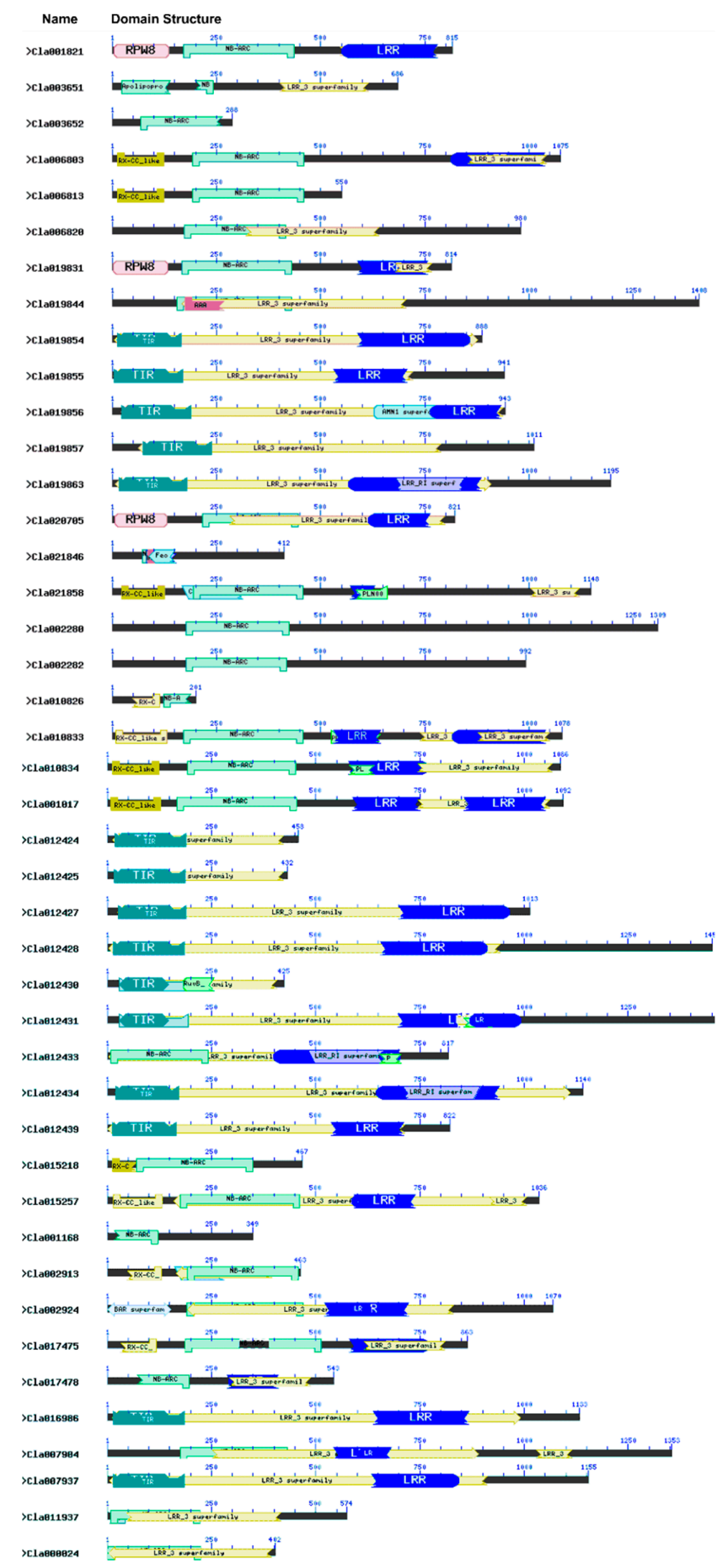

Figure 3. Domains present in NBS proteins in watermelon. The conserved domains were identified using the Conserved Domain Database (CDD) of NCBI against the Pfam v30.0 database (https: / / www. ncbi.nlm.nih.gov/Structure/cdd/wrpsb.cgi). Detailed descriptions of these domains are provided in Table 2. Specific domains in each protein are shown in the diagram. 
Table 2. Key domains in the 44 watermelon NBS proteins.

\begin{tabular}{lllll}
\hline S1. No. & Domain Name & Description & Function & Reference \\
\hline 1 & RPW8 & Resistance to Powdery Mildew8 & Involved in powdery & mildew resistance \\
2 & LRR & Leucine-rich repeats & Disease resistance & {$[23]$} \\
3 & NB-ARC & Nucleotide-binding adaptor shared & Disease resistance & {$[25,26]$} \\
4 & by APAF-1, R proteins and CED-4 & Plant defense & {$[25]$} \\
5 & CC & Toll-interleukin 1-receptor & Disease resistance & {$[27,28]$} \\
\hline
\end{tabular}

Table 3. Classification of the 44 Citrullus lanatus NBS-encoding genes.

\begin{tabular}{cll}
\hline Sl. No. & \multicolumn{1}{c}{ Type } & \multicolumn{1}{c}{ Gene Name } \\
\hline 1 & NBS & Cla003652, Cla002280, Cla002282 and Cla001168 \\
2 & NBS-LRR & Cla001821, Cla003651, Cla006820, Cla019831, Cla012433 and Cla017478 \\
3 & LRR & Cla002924, Cla011937 and Cla000024 \\
4 & RPW8-NBS-LRR & Cla001821, Cla019831 and Cla020705 \\
5 & TIR & Cla012424, Cla012425 and Cla012430 \\
6 & TIR-LRR & Cla019854,Cla019855, Cla019856, Cla019857, Cla019863, Cla012427, Cla012428, \\
7 & CC-NBS & Cla012431, Cla012439, Cla016986 and Cla007937 \\
8 & CC-NBS-LRR & Cla006813, Cla010826, Cla015218 and Cla002913 \\
\end{tabular}

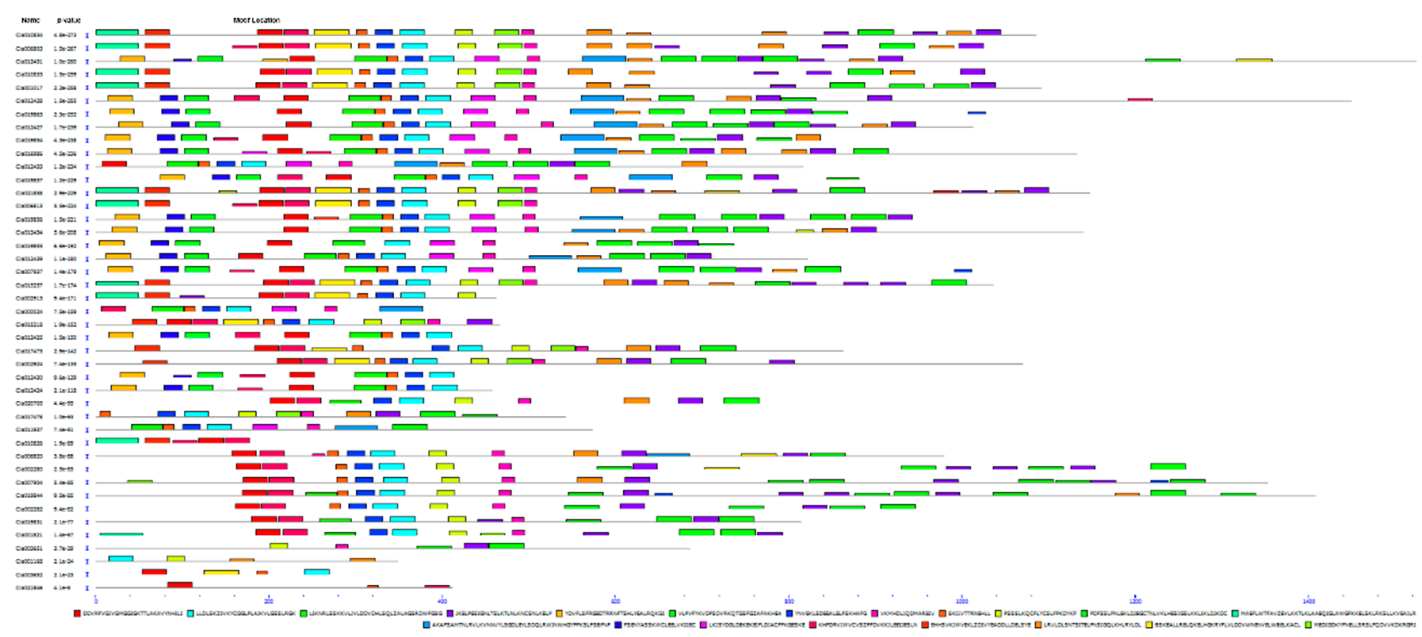

Figure 4. Conserved motifs of NBS-encoding $R$ genes in the watermelon genome. Motifs are indicated by different colored rectangles. Detailed information is provided in Table 4 .

Table 4. Putative conserved motifs in the 44 watermelon NBS proteins.

\begin{tabular}{llccl}
\hline Motif Name & E-Value & Sites & Width & \multicolumn{1}{c}{ Motif Sequence } \\
\hline Motif 1 & $1.2 \times 10^{-386}$ & 38 & 29 & DDVRFVGIVGMGGIGKTTLAKAVYNHILI \\
Motif 2 & $2.30 \times 10^{-290}$ & 40 & 29 & LLDLSKEIVKYCGGLPLAJKVLGSSLRGK \\
Motif 3 & $1.70 \times 10^{-232}$ & 17 & 37 & IIKNRLSSKKVLJVLDDVDELEQLZALAGGRDWFGPG \\
Motif 4 & $1.50 \times 10^{-220}$ & 33 & 29 & JKELPESIGNLTSLKTLNLKNCSNLKELP \\
Motif 5 & $1.30 \times 10^{-204}$ & 15 & 29 & YDVFLSFRGEDTRRNFTSHLYEALRQKGI \\
Motif 6 & $4.90 \times 10^{-189}$ & 15 & 29 & VLPVFYKVDPSDVRKQTGSFGZAFAKHEA \\
Motif 7 & $1.70 \times 10^{-187}$ & 34 & 21 & KVKMHDLIQDMARTIVRKZSV \\
Motif 8 & $1.80 \times 10^{-167}$ & 37 & 21 & YNVEKLSDEEALELFSKHAFG \\
Motif 9 & $3.40 \times 10^{-119}$ & 35 & 13 & SKIIVTTRNEHLL \\
Motif 10 & $1.00 \times 10^{-117}$ & 21 & 21 & PSSSLKQCFLYCSLFPKDYKF \\
Motif 11 & $1.10 \times 10^{-171}$ & 28 & 41 & PDFSSLPNLEKLDJEGCTNLVKLHESIGSLKKLIKLDJKDC \\
Motif 12 & $1.50 \times 10^{-157}$ & 8 & 50 & MAEFLWTFAVZEVLKKTLKLAAEQIGLAWGFKKELSKLRKSLLKVEAILR \\
Motif 13 & $7.60 \times 10^{-122}$ & 13 & 21 & FSENYASSKWCLEELVKIIEC \\
Motif 14 & $2.10 \times 10^{-126}$ & 22 & 29 & KHFDKVIWVCVSZPFDVKKILEEIJESLN \\
Motif 15 & $1.10 \times 10^{-109}$ & 15 & 27 & KEIFLDIACFFKGEDVELVKEILEACG \\
Motif 16 & $6.60 \times 10^{-92}$ & 11 & 29 & EHHSVKJWVEKLZDIVYEADDLLDELSYE \\
Motif 17 & $8.20 \times 10^{-90}$ & 10 & 34 & NSSGGLDSKEALLRELQKELHGKRYFLVLDDVWN \\
Motif 18 & $5.70 \times 10^{-92}$ & 11 & 29 & TMEDIGDKYFNELLSRSLFQDVVKDKRGR \\
Motif 19 & $4.90 \times 10^{-78}$ & 13 & 29 & SWHGFPFKSLPSDFHPENLVELDLRYSCI \\
Motif 20 & $7.60 \times 10^{-97}$ & 22 & 29 & SLRVLDLSNTNITKLPNSIGQLKHLRYLD \\
\hline
\end{tabular}


2.4. Synteny Analysis of 44 NBS-Encoding R Genes of C. lanatus Compared with Cucumis melo, Cucumis satious, and A. thaliana

We performed comparative analysis to identify the homologous NBS-encoding $R$ genes among C. lanatus, Cucumis melo, Cucumis sativus and A. thaliana, with the results shown in Figure 5. Most $R$ genes from $C$. lanatus share homologous relationships with those of Cucumis melo, Cucumis sativus and A. thaliana. However, five genes (Cla000024, Cla019844, Cla002280, Cla002282 and Cla011937) lack homologues in Cucumis melo and three (Cla000024, Cla019844 and Cla002280) lack homologues in Cucumis sativus. On the other hand, all $44 R$ genes of $C$. lanatus have homologues in $A$. thaliana.

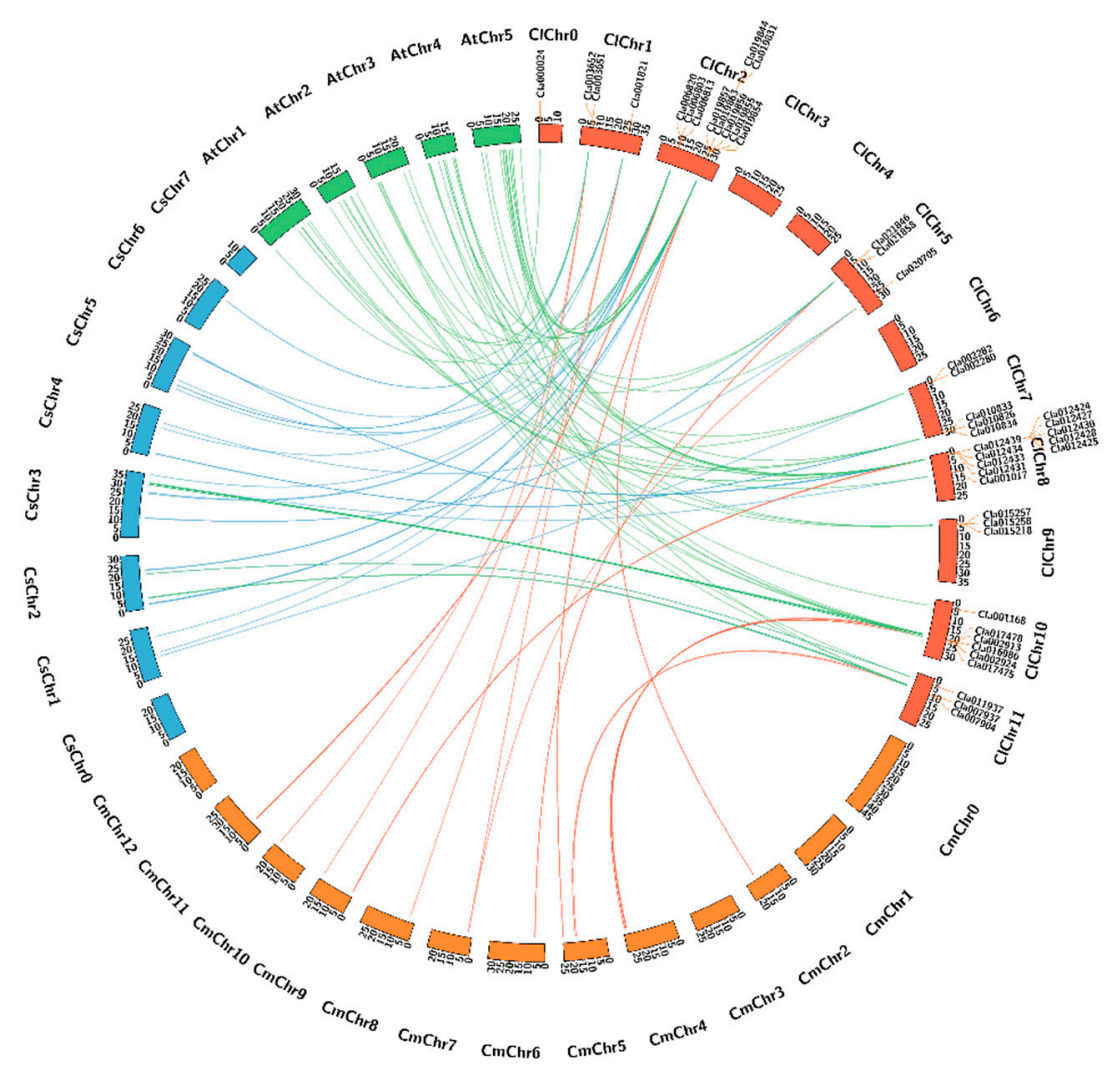

Figure 5. Microsynteny analysis of the 44 watermelon NBS-encoding $R$ genes compared to those of Cucumis melo, Cucumis sativus and A. thaliana. Brown orange, blue and green indicate C. lanatus, Cucumis melo, Cucumis sativus and A. thaliana chromosomes, respectively.

\subsection{Expression Patterns of the NBS-Encoding R Genes in Resistant and Susceptible Watermelon Lines}

GSB, which is one of the most devastating diseases of cucurbits, significantly reduces the yield and quality of watermelon. To gain insight into the roles of NBS-encoding genes in the response to GSB in watermelon, we designed specific primers for the 44 NBS-encoding $R$ genes and analyzed their expression patterns following inoculation with $D$. bryoniae at various time points. Several genes were differentially expressed in the leaf tissue of the resistant compared to susceptible watermelon lines (Figure 6). Among these, six genes (Cla001821, Cla019863, Cla020705, Cla012430, Cla012433 and Cla012439) were expressed at higher levels in the resistant line compared to the susceptible line. These genes belong to the same cluster in the heat map (Figures 6 and 7). The transcript levels of five of these six genes reached a peak at $12 \mathrm{~h}$ postinoculation with $D$. bryoniae in the resistant line, whereas Cla001821 transcript levels reached a peak at $72 \mathrm{~h}$ postinoculation. Finally, the transcript levels of Cla020705 peaked at both 12 and $72 \mathrm{~h}$ postinoculation in the resistant line. 


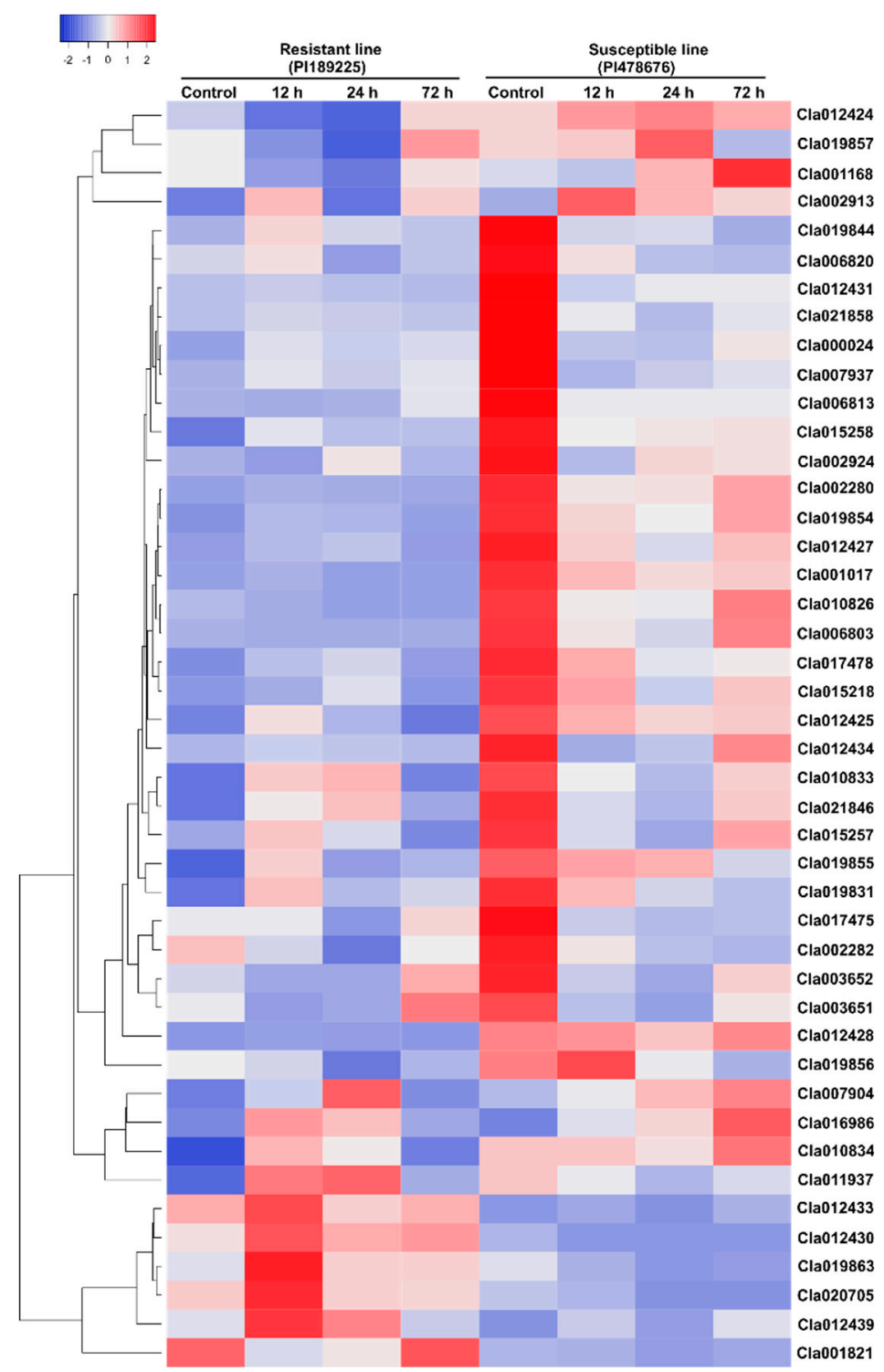

Figure 6. Heat map of the expression patterns of the 44 NBS-encoding $R$ genes determined by qRT-PCR in gummy stem blight resistant and susceptible watermelon lines subjected to Didymella bryoniae infection at various time points. The expression levels were normalized with the Actin gene. The values were obtained from the means of three technical replicates. Red and blue represent the maximum and minimum values, respectively. The heat map was generated with an online tool 'Heatmapper' (http://www.heatmapper.ca/expression/). 

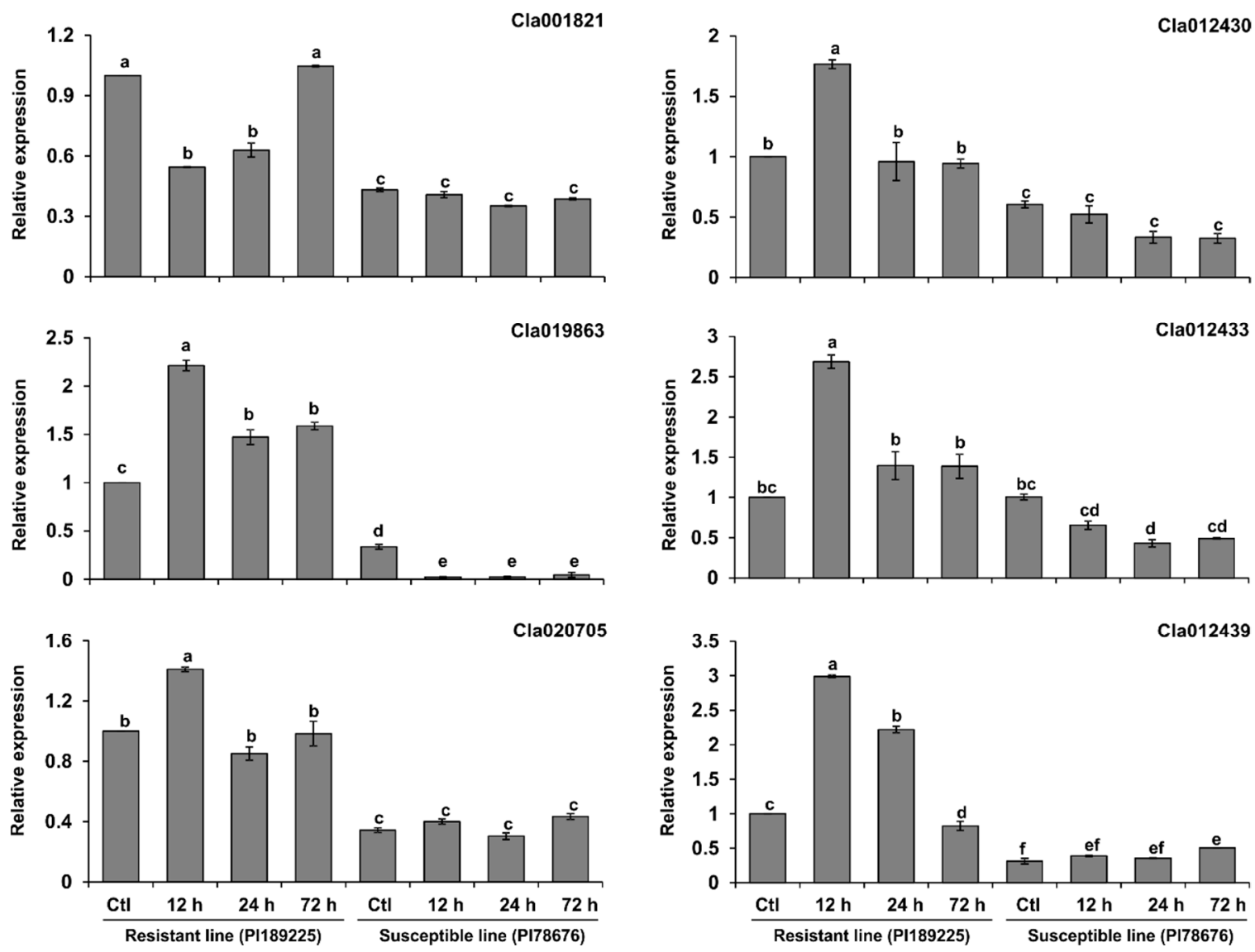

Figure 7. Relative expression levels of candidate NBS-encoding $R$ genes in Didymella bryoniae-resistant and susceptible watermelon lines. Error bars represent \pm SE of the means of three technical replicates. Different letters above the bars indicate significant differences.

\section{Discussion}

Watermelon is an economically important fruit crop that is widely cultivated throughout the tropical and subtropical regions of the world. Watermelon is frequently affected by fungal, bacterial, viral and insect pests. GSB is a severe disease of watermelon caused by the fungus $D$. bryoniae, which significantly reduces fruit yields and quality. To reduce crop losses due to GSB, it is important to investigate the mechanism underlying the resistance to this disease. The ultimate target of both breeders and researchers is to develop GSB-resistant cultivars, since chemical treatment is not an environmentally suitable approach for controlling GSB [29]. Gene pyramiding is an effective way to increase the chances of conferring stable resistance to plant diseases, but disease resistance can break down due to increasing mutation rates in the pathogen population $[9,30]$.

NBS-encoding $R$ genes play important roles in plant protection against a diverse range of pathogens, including fungi, bacteria, viruses, aphids and nematodes [15,31]. For example, the $R$ genes Fom1, Prv and Vat are responsible for resistance to Fusarium, Papaya ringspot virus and aphid resistance in melon, respectively [32,33]. The RPS6 gene plays a role in resistance against the bacterium Pseudomonas syringae in A. thaliana [14]. In addition, the $R$ gene Bo1037156 (FOC1) confers resistance to the fungal pathogen Fusarium in Brassica oleracea [34]. NBS-LRR disease resistance genes have been extensively studied in various plant species, such as Cucumis melo [35], Arabidopsis [36], Oryza sativa [17], Zea mays [37], Solanum tuberosum [38] and Glycine max [39]. However, the roles of NBS-LRR genes in response to $D$. bryoniae infection in watermelon have not been reported. The analysis of 44 NBS-encoding genes performed in this study revealed that these genes encode TIR-LRR, CC-NBS and CC-NBS-LRR proteins (Table 3). These genes are distributed throughout all watermelon chromosomes except $\mathrm{Chr} 3$, Chr4 and Chr6, with at least one gene per chromosome (Figure 1). 
The analysis of qRT-PCR expression revealed that various genes were differentially expressed in resistant compared to susceptible watermelon. Consistent expression patterns were detected for six genes, with higher levels of expression in the resistant line compared to the susceptible line (Figures 6 and 7). These candidate genes belong to different categories, including NBS-LRR (Cla012433), RPW8-NBS-LRR (Cla001821), RPW8-LRR (Cla020705), TIR (Cla012430) and TIR-LRR (Cla012439 and Cla019863) (Table 3). NBS-encoding genes contribute to disease resistance in various plant species. For example, TIR-NBS-LRR-type $R$ genes confer resistance to tobacco mosaic virus in Nicotiana benthamiana and GSB in Cucumis melo [5,40]. In indica rice, the $R$ gene Os11g0704100 (Pia), which encodes an NBS-LRR domain-containing protein, functions in rice blast resistance, with significantly higher expression detected in resistant compared to susceptible land races both before and after pathogen inoculation [41]. In Arabidopsis, the expression levels of four TIR-NBS (TN) genes increased upon treatment with different pathogens [42]. Finally, three NBS-encoding genes (Bo1010559, Bo129866 and Bo1042121) were recently shown to function in resistance to black rot in cabbage (Brassica oleracea var. capitata), with higher expression levels detected in the resistant line compared to the susceptible lines [43].

In this study, we identified six candidate genes for GSB resistance, including Cla012430, Cla012433 and Cla012439 on Chr8 and Cla001821, Cla019863 and Cla020705 on Chr1, Chr2 and Chr5, respectively. The existence of homologues of these candidate genes in melon, cucumber and Arabidopsis (Figure 5) indicates that these genes likely play similar roles in these plants. Although GSB is a major yield-limiting factor for watermelon, few genetic studies have focused on this disease. Moreover, to date, no quantitative trait loci associated with GSB resistance in watermelon have been identified. To our knowledge, this is the first report of candidate genes for GSB resistance in watermelon.

\section{Materials and Methods}

\subsection{Experimental Materials}

The GSB-resistant 'PI189225' and -susceptible 'PI438676' (Charleston Gray) watermelon inbred lines used in this study were obtained from National Plant Germplasm System (NPGS), U.S. Department of Agriculture (USDA). The resistance and susceptibility of these lines were previously assessed via bioassay screening using the fungus D. bryoniae $[4,44]$. In this study, these lines were reexamined using an intensive bioassay, which confirmed the GSB resistance of 'PI189225' and the susceptibility of 'PI438676' (Figure 8). The seeds were sown in a commercial soil mixture in a 32-hole plastic tray and transferred to a plant growth chamber at a constant temperature of $25 \pm 1{ }^{\circ} \mathrm{C}$, relative humidity of $60 \%$ and light intensity of $80-120 \mu \mathrm{mol} . \mathrm{m}^{-2} \cdot \mathrm{s}^{-1}$. Two weeks after germination, the plants were transferred to plastic pots and grown in a glasshouse where plants were inoculated with $D$. bryoniae, which was maintained at $24 \pm 2{ }^{\circ} \mathrm{C}$ temperature with $90 \%$ relative humidity. 


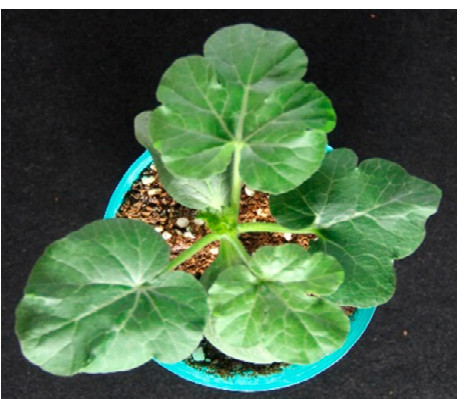

PI189225 (Control)

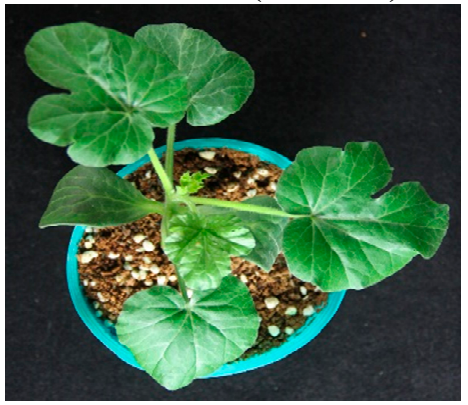

PI189225 (Inoculated)

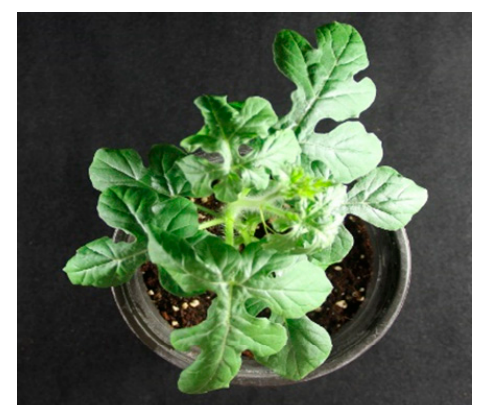

PI438676 (Control)

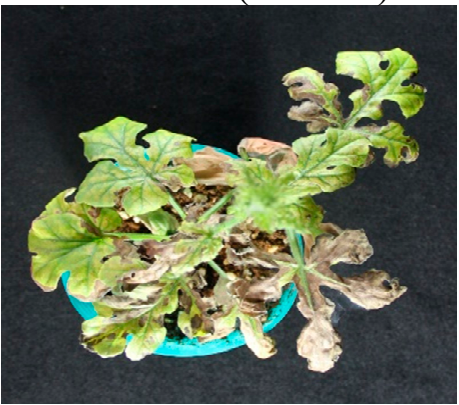

PI438676 (Inoculated)

Figure 8. Phenotypes of watermelon lines PI189225 (resistant) and PI438676 (susceptible) after inoculation with Didymella bryoniae.

\subsection{Pathogen Inoculation and Sampling}

A D. bryoniae fungal isolate (13-020) was collected from National Institute of Horticulture and Herbal Sciences (NIHHS), Republic of Korea. The fungus was cultured in potato dextrose agar (PDA) medium at $24 \pm 2{ }^{\circ} \mathrm{C}$ under alternating periods of 12 -h fluorescent light $\left(40-90 \mu \mathrm{mol} \cdot \mathrm{m}^{-2} \cdot \mathrm{sec}^{-1} \mathrm{PPFD}\right)$ and 12-h darkness for 2-3 weeks until pycnidia formed. The final concentration of the fungal spores was adjusted to $5 \times 10^{5}$ spores $\mathrm{mL}^{-1}$ with deionized water. For fungal inoculation, 28-day-old resistant and susceptible plants were inoculated with $D$. bryoniae by hand using a spray bottle, whereas control resistant and susceptible plants were sprayed with plain water. The inoculated plants were incubated in a growth chamber with a relative humidity of $90-95 \%$ and a temperature of $24{ }^{\circ} \mathrm{C}$. Samples were collected from the third and fourth true leaves of the plants at the time points 12,24 and $72 \mathrm{~h}$ after inoculation and from control plants at the same time points. The samples were immediately frozen in liquid nitrogen and stored at $-80^{\circ} \mathrm{C}$.

\subsection{Total RNA Isolation and $c D N A$ Synthesis}

Infected and control watermelon leaves were ground to a powder in liquid nitrogen and $100 \mathrm{mg}$ of each sample was subjected to total RNA extraction using an RNeasy Mini kit (Qiagen, Valencia, CA) following the manufacturer's instructions. First-strand cDNA was synthesized from total RNA with a SuperScript III First-Strand Synthesis System kit (Invitrogen, Gaithersburg, MD).

\subsection{Exploring NBS-Encoding Genes in C. lanatus}

Few genetic studies of GSB resistance in watermelon have been performed. However, 44 NBS-LRR genes have been identified by genomic analysis [1] and these genes were subjected to expression analysis in this study (Table 5).

\subsection{Quantitative RT-PCR Analysis}

The expression patterns of the 44 NBS-encoding genes were analyzed by quantitative RT-PCR (qRT-PCR) in a LightCycler ${ }^{\circledR}$ instrument (Roche, Mannheim, Germany) following the manufacturer's 
instructions. The gene sequences used in this study were retrieved from the Cucurbit Genomics Database (http:/ / cucurbitgenomics.org/) considering ' 97103 ' as the reference genome for watermelon. Gene-specific primers for qRT-PCR were designed using Primer3Plus (https:/ / primer3plus.com/ cgibin/dev/primer3plus.cgi) (Table 5 and Table S1). The reactions were performed in a 10- $\mu \mathrm{L}$ volume consisting of $5 \mu \mathrm{L}$ of $2 \times$ qPCRBIO SyGreen Mix Lo-ROX (PCR Biosystems, London, UK), 5 pmol of primers and cDNA templates diluted to the appropriate concentrations. The PCR conditions were as follows: $5 \mathrm{~min}$ at $95^{\circ} \mathrm{C}$, followed by 3-step amplifications at $95^{\circ} \mathrm{C}$ for $15 \mathrm{~s}, 58{ }^{\circ} \mathrm{C}$ for $15 \mathrm{~s}$ and $72{ }^{\circ} \mathrm{C}$ for $20 \mathrm{~s}$ for 45 cycles. The relative expression level of each gene was evaluated using the comparative $2^{-\triangle \Delta C T}$ method, with Actin used as an internal control [45].

Table 5. Primers for the 44 NBS-encoding genes in watermelon.

\begin{tabular}{|c|c|c|c|c|}
\hline S1. No. & Gene Name & Forward Primer & Reverse Primer & Product Size (bp) \\
\hline 1 & Cla001821 & ACTGTCTAACGAGTCTTGAACG & TTCTCCAGATTTATCAGCGGT & 94 \\
\hline 2 & Cla003651 & ATCTCTCGATTATGTGGGCGG & TTGGGTGGCACGGTTACTCTG & 118 \\
\hline 3 & Cla003652 & TCCCAAAATCGCTCTTCTGC & AGATACCGTTTGCCTCTCAGT & 126 \\
\hline 4 & Cla006803 & GGAAACGATCCAAACCATAGG & СТTСССТTTGСТССАAGTTGA & 85 \\
\hline 5 & Cla006813 & AACTCATGGAAACACGCCCTA & CCAATGGTACGCCACCAACT & 165 \\
\hline 6 & Cla006820 & AGGTTGTATCAGAGATGAGTTC & CATATTCATTAGAAGCCGTGGGT & 108 \\
\hline 7 & Cla019831 & GGAGTGTTTCATGGACTTGG & TTCATGTGCTTCGTTTCTCA & 178 \\
\hline 8 & Cla019844 & AGTGTTGAAGGAAGAGCAGCC & TAAATCAAGTCССТСССАСА & 96 \\
\hline 9 & Cla019854 & ACAAATGGGTCGCACAATCGC & TGGCTTTAACTGCTCTTGCT & 131 \\
\hline 10 & Cla019855 & GTGAGGTACGAAAACAAACTGG & ACAACCCAGCAGCAGTAGTC & 122 \\
\hline 11 & Cla019856 & GTCAACAAACATCCGAGGATTA & TCAAGGTTTAATGTCGCCGAG & 116 \\
\hline 12 & Cla019857 & CCAGTCTTCCTTGTTGGATGG & CCATCCAACAAGGAAGACTGG & 171 \\
\hline 13 & Cla019863 & GTATAGGAAGCTGTGGCGTCC & TCCCCAGTGTCCGGATTTTGC & 127 \\
\hline 14 & Cla020705 & GTTGTCACGAGGCGAGCCTAT & TTTGTCTTCAGGAAAGCATCCC & 133 \\
\hline 15 & Cla021846 & СCTGACCCATCTTCTCCTATT & ATCTTGCACTTTCGCATGAACA & 135 \\
\hline 16 & Cla021858 & GAAACCATGGAAGACATAGGAG & TGAGACAGAATAAGCAAGATCG & 144 \\
\hline 17 & Cla002280 & AGATGGGGAGCGGAAGTATCA & СССАТТТСТАТАСТСААСТСАG & 146 \\
\hline 18 & Cla002282 & GGTTAGAAGATGATAGACGTGG & GGAAACTCCAACTCCAGGGGA & 91 \\
\hline 19 & Cla010826 & TGTGGCATGGGGCTTGGACA & GATCCTTCACССАСААТСТCAC & 128 \\
\hline 20 & Cla010833 & AGTGTGGATCGCCTACCGTCA & САTTCCTTTCCTCAGATGGTCG & 145 \\
\hline 21 & Cla010834 & CTCCGACCCTTGTGATGCTA & ACATCCATCATCAAACCCAACT & 100 \\
\hline 22 & Cla001017 & GCAAACATTGTGGAGACGCAT & CAAGCACTTCTCGAACTACA & 145 \\
\hline 23 & Cla012424 & GTGGGGATGTGTAGTATTGGTA & ATCAATGCGAAGGAAGCAACTA & 99 \\
\hline 24 & Cla012425 & AGCGGGAGGTGATTCAAAGC & GAACCTTTCTACCACTCAGTCG & 143 \\
\hline 25 & Cla012427 & CAGCCGAGTGAACTATTGGAAC & GCACCATTGACAGATCAGGG & 145 \\
\hline 26 & Cla012428 & TCCAGCATTCGATGTTTACTCG & ACCATTCCAATAGGTCAACATC & 99 \\
\hline 27 & Cla012430 & TGGTTGGAATTAGCCACAGATT & CCAATTCCACCCATTCCCCATA & 100 \\
\hline 28 & Cla012431 & GCTTGGATCCTCAATCACAGTC & GAGAGTTTTGTAGCACTTGGAAG & 116 \\
\hline 29 & Cla012433 & GGATTTGGATGAGGAAGGAGAA & GTATCCATGCCAATTGAGAAAC & 151 \\
\hline 30 & Cla012434 & СТCTCATCTTCCAACAAGCATA & TCCTTGGAGGTAGCTCTGGGA & 101 \\
\hline 31 & Cla012439 & GCGGCATTGGCAAGACGACA & AATAAGGAAGATTGTGGGTCTC & 120 \\
\hline 32 & Cla015218 & GTTGAAAGGGTCTCCTCTTGC & GTGCAAAGTTCACTGTCCTTGA & 102 \\
\hline 33 & Cla015257 & GGGAAGTTGAGTTGTCTACAGA & СTAAACTGACTTCAGATGGACT & 157 \\
\hline 34 & Cla015258 & GTGGAGTCAAATTTCCCAACTG & CCAAATATAGAGAATGGAGAGC & 132 \\
\hline 35 & Cla001168 & GTGTACCAAGCGTTTGGAGTT & TACTTAACCTGCCСCTCAACT & 163 \\
\hline 36 & Cla002913 & AGAATGGCTTATGGGACGAGC & TGGTTGCCACTTCTAGGTTCC & 102 \\
\hline 37 & Cla002924 & СТCAATTCCСТTCAAACACTGA & GCTCACACCCCCATATTGCC & 112 \\
\hline 38 & Cla017475 & GGTCGTTACCGGAAGATACTCA & CATCTAGCTCATTCAGAGGGC & 123 \\
\hline 39 & Cla017478 & CCCAGTCACAGAACCTAAATCT & CAGCATTTGGTATTTCCCGTAG & 149 \\
\hline 40 & Cla016986 & CTTTTGGAAGGAGTGTAAGTTG & TTCTCTAGATTTGGGAGTTTGG & 108 \\
\hline 41 & Cla007904 & GCAGCATCCACACAGTGCCTT & GGAAAGACATTTGTGGAAGCC & 104 \\
\hline 42 & Cla007937 & AAGATCGACCGCCTCCACGA & CCGATCTTCTGCAGTTACAAC & 154 \\
\hline 43 & Cla011937 & GAGAGGATGTTGAACTTGCCAG & GCTTTCCACATCTCTTGAATCA & 154 \\
\hline 44 & Cla000024 & GACATTGAAGGCATAGTGATGG & CCATGCCAATTGAGAAACCTC & 167 \\
\hline Actin & Cla007792 & CCATGTATGTTGCCATCCAG & GGATAGCATGGGGTAGAGCA & 140 \\
\hline
\end{tabular}

\subsection{Statistical Analysis}

Analysis of variance (ANOVA) and significance tests were carried out using the normalized gene expression values with MINITAB17 software (Minitab Inc., State College, PA, USA). The means were separated by Tukey's pairwise comparisons. 


\section{Conclusions}

We identified six candidate genes that might be involved in the response of watermelon to D. bryoniae infection based on their expression profiles in resistant and susceptible watermelon lines. This study provides the basis for further functional studies to confirm the association of NBS-LRR genes with GSB resistance in watermelon. In addition, our results should facilitate marker-assisted breeding for developing GSB-resistant watermelon cultivars through gene pyramiding.

Supplementary Materials: Supplementary materials can be found at http:/ /www.mdpi.com/1422-0067/20/4/ 902/s1.

Author Contributions: I.-S.N., H.-T.K. and J.-I.P. conceived the study. M.Z.H. conducted the experiments and wrote the manuscript. H.-J.J. helped carry out the qRT-PCR assay. M.A.R. analyzed the qRT-PCR data, created the figures, performed the bioinformatics analysis and edited the manuscript. All authors read and approved the final version of the manuscript.

Funding: This study was supported by the Golden Seed Project (Center for Horticultural Seed Development, grant number 213007-05-3-CG100) of the Ministry of Agriculture, Food and Rural Affairs (MAFRA) of the Republic of Korea.

Conflicts of Interest: The authors declare no conflict of interest.

\section{References}

1. Xu, Y.; Wang, J.; Guo, S.; Zhang, J.; Sun, H.; Salse, J.; Lucas, W.J.; Zhang, H.; Zheng, Y.; Mao, L.; et al. The draft genome of watermelon (Citrullus lanatus) and resequencing of 20 diverse accessions. Nat. Genet. 2013, 45, 51-58.

2. Perkins-Veazie, P.; Collins, J.K.; Davis, A.R.; Roberts, W. Carotenoid content of 50 watermelon cultivars. J. Agric. Food Chem. 2006, 54, 2593-2597. [CrossRef] [PubMed]

3. Keinath, P.K. Fungicide Timing for Optimum Management of Gummy Stem Blight Epidemics on Watermelon. Plant Dis. 1995, 79, 354. [CrossRef]

4. Gusmini, G.; Song, R.; Wehner, T.C. Inheritance of resistance to gummy stem blight in watermelon. Hoert Sci. 2017, 52, 1477-1482. [CrossRef]

5. Hassan, M.Z.; Rahim, M.A.; Natarajan, S.; Robin, A.H.K.; Kim, H.T.; Park, J.I.; Nou, I.S. Gummy Stem Blight Resistance in Melon: Inheritance Pattern and Development of Molecular Markers. Int. J. Mol. Sci. 2018, 19, 2914. [CrossRef] [PubMed]

6. Zuniga, T.L.; Jantz, J.P.; Zitter, T.A.; Jahn, M.M. Monogenic dominant resistance to gummy stem blight in two melon (Cucumis melo) accessions. Plant Dis. 1999, 83, 1105-1107. [CrossRef]

7. Song, R.; Gusmini, G.; Wehner, T.C. Screening the watermelon germplasm collection for resistance to gummy stem blight. Acta Hortic. 2004, 637, 63-68. [CrossRef]

8. Hassan, Z.; Hasan, A.; Robin, K.; Rahim, A.; Natarajan, S. Screening of melon genotypes identifies gummy stem blight resistance associated with Gsb1 resistant loci. J. Plant Biotechnol. 2018, 2818, 217-227. [CrossRef]

9. Zhang, N.; Xu, B.H.; Bi, Y.F.; Lou, Q.F.; Chen, J.F.; Qian, C.T.; Zhang, Y.B.; Yi, H.P. Development of a muskmelon cultivar with improved resistance to gummy stem blight and desired agronomic traits using gene pyramiding. Czech J. Genet. Plant Breed. 2017, 53, 23-29. [CrossRef]

10. Norton, J.D.; Boyhan, G.E.; Smith, D.A.; Abrahams, B.R. 'AU-Sweet Scarlet' watermelon. Hortscience 1995, 30, 393-394. [CrossRef]

11. Zhong, Y.; Zhang, X.; Cheng, Z.M. Lineage-specific duplications of NBS-LRR genes occurring before the divergence of six Fragaria species. BMC Genom. 2018, 19, 1-15. [CrossRef] [PubMed]

12. Slootweg, E.; Koropacka, K.; Roosien, J.; Dees, R.; Overmars, H.; Lankhorst, R.K.; van Schaik, C.; Pomp, R.; Bouwman, L.; Helder, J.; et al. sequence exchange between homologous NB-LRR genes converts virus resistance into nematode resistance and vice versa. Plant Physiol. 2017, 175, 498-510. [CrossRef]

13. Bonas, U.; Van Den Ackerveken, G. Gene-for-gene interactions: Bacterial avirulence proteins specify plant disease resistance. Curr. Opin. Microbiol. 1999, 2, 94-98. [CrossRef]

14. Yu, J.; Tehrim, S.; Zhang, F.; Tong, C.; Huang, J.; Cheng, X.; Dong, C.; Zhou, Y.; Qin, R.; Hua, W.; et al. Genome-wide comparative analysis of NBS-encoding genes between Brassica species and Arabidopsis thaliana. BMC Genom. 2014, 15. [CrossRef] [PubMed] 
15. Marone, D.; Russo, M.A.; Laidò, G.; De Leonardis, A.M.; Mastrangelo, A.M. Plant nucleotide binding site-leucine-rich repeat (NBS-LRR) genes: Active guardians in host defense responses. Int. J. Mol. Sci. 2013, 14, 7302-7326. [CrossRef] [PubMed]

16. Meyers, B.C.; Kozik, A.; Griego, A.; Kuang, H.; Michelmore, R.W. Genome-wide analysis of NBS-LRR_Encoding genes in Arabidopsis. Plant Cell 2003, 15, 809-834. [CrossRef] [PubMed]

17. Zhou, T.; Wang, Y.; Chen, J.Q.; Araki, H.; Jing, Z.; Jiang, K.; Shen, J.; Tian, D. Genome-wide identification of NBS genes in japonica rice reveals significant expansion of divergent non-TIR NBS-LRR genes. Mol. Genet. Genom. 2004, 271, 402-415.

18. Monosi, B.; Wisser, R.J.; Pennill, L.; Hulbert, S.H. Full-genome analysis of resistance gene homologues in rice. Theor. Appl. Genet. 2004, 109, 1434-1447. [CrossRef]

19. Natarajan, S.; Kim, H.T.; Thamilarasan, S.K.; Veerappan, K.; Park, J.I.; Nou, I.S. Whole genome re-sequencing and characterization of powdery mildew disease-associated allelic variation in melon. PLoS ONE 2016, 11, 1-19. [CrossRef]

20. Wan, H.; Yuan, W.; Bo, K.; Shen, J.; Pang, X.; Chen, J. Genome-wide analysis of NBS-encoding disease resistance genes in Cucumis sativus and phylogenetic study of NBS-encoding genes in Cucurbitaceae crops. BMC Genom. 2013, 14, 109. [CrossRef]

21. Lee, S.Y.; Seo, J.S.; Rodriguez-Lanetty, M.; Lee, D.H. Comparative analysis of superfamilies of NBS-encoding disease resistance gene analogs in cultivated and wild apple species. Mol. Genet. Genom. 2003, 269, 101-108.

22. Voorrips, R.E. MapChart: Software for the Graphical Presentation of Linkage Maps and QTLs. J. Hered. 2002, 93, 77-78. [CrossRef] [PubMed]

23. Xiao, S.; Ellwood, S.; Calis, O.; Patrick, E.; Li, T.; Coleman, M.; Turner, J.G. Broad-spectrum mildew resistance in Arabidopsis thaliana mediated by RPW8. Science 2001, 291, 118-120. [CrossRef] [PubMed]

24. $\mathrm{Ng}$, A.; Xavier, R.J. Leucine-rich repeat (LRR) proteins: Integrators of pattern recognition and signaling in immunity. Autophagy 2011, 7, 1082-1084. [CrossRef] [PubMed]

25. van der Biezen, E.A.; Jones, J.D.G. The NB-ARC domain: a novel signalling motif shared by plant resistance gene products and regulators of cell death in animals. Curr. Biol. 1998, 8, R226-R228. [CrossRef]

26. Chandra, S.; Kazmi, A.Z.; Ahmed, Z.; Roychowdhury, G.; Kumari, V.; Kumar, M.; Mukhopadhyay, K. Genome-wide identification and characterization of NB-ARC resistant genes in wheat (Triticum aestivum L.) and their expression during leaf rust infection. Plant Cell Rep. 2017, 36. [CrossRef] [PubMed]

27. Song, H.; Wang, P.; Li, C.; Han, S.; Zhao, C.; Xia, H.; Bi, Y.; Guo, B.; Zhang, X.; Wang, X. Comparative analysis of NBS-LRR genes and their response to Aspergillus flavus in Arachis. PLoS ONE 2017, 12, 1-14. [CrossRef] [PubMed]

28. Moffett, P.; Farnham, G.; Peart, J.; Baulcombe, D.C. Interaction between domains of a plant NBS-LRR protein in disease resistance-related cell death. Embo J. 2002, 21, 4511-4519. [CrossRef]

29. Wolukau, J.N.; Zhou, X.; Chen, J.F. Identification of amplified fragment length polymorphism markers linked to gummy stem blight (Didymella bryoniae) resistance in melon (Cucumis melo L.) PI 420145. HortScience 2009, 44, 32-34. [CrossRef]

30. Hanson, P.; Lu, S.F.; Wang, J.F.; Chen, W.; Kenyon, L.; Tan, C.W.; Tee, K.L.; Wang, Y.Y.; Hsu, Y.C.; Schafleitner, R.; et al. Conventional and molecular marker-assisted selection and pyramiding of genes for multiple disease resistance in tomato. Sci. Hortic. 2016, 201, 346-354. [CrossRef]

31. Gururani, M.A.; Venkatesh, J.; Upadhyaya, C.P.; Nookaraju, A.; Pandey, S.K.; Park, S.W. Plant disease resistance genes: Current status and future directions. Physiol. Mol. Plant Pathol. 2012, 78, 51-65. [CrossRef]

32. Brotman, Y.; Normantovich, M.; Goldenberg, Z.; Zvirin, Z.; Kovalski, I.; Stovbun, N.; Doniger, T.; Bolger, A.M.; Troadec, C.; Bendahmane, A.; et al. Dual resistance of melon to Fusarium oxysporum races 0 and 2 and to papaya ring-spot virus is controlled by a pair of head-to-head-oriented nb-lrr genes of unusual architecture. Mol. Plant 2013, 6, 235-238. [CrossRef] [PubMed]

33. Dogimont, C.; Chovelon, V.; Pauquet, J.; Boualem, A.; Bendahmane, A. The Vat locus encodes for a CC-NBS-LRR protein that confers resistance to Aphis gossypii infestation and A. gossypii-mediated virus resistance. Plant J. 2014, 80, 993-1004. [CrossRef] [PubMed]

34. Lv, H.; Fang, Z.; Yang, L.; Zhang, Y.; Wang, Q.; Liu, Y.; Zhuang, M.; Yang, Y.; Xie, B.; Liu, B.; et al. Mapping and analysis of a novel candidate Fusarium wilt resistance gene FOC1 in Brassica oleracea. BMC Genom. 2014, 15, 1094. [CrossRef] [PubMed] 
35. Garcia-Mas, J.; Benjak, A.; Sanseverino, W.; Bourgeois, M.; Mir, G.; Gonzalez, V.M.; Henaff, E.; Camara, F.; Cozzuto, L.; Lowy, E.; et al. The genome of melon (Cucumis melo L.). Proc. Natl. Acad. Sci. USA 2012, 109, 11872-11877. [CrossRef] [PubMed]

36. Martin, G.B.; Bogdanove, A.J.; Sessa, G. Understanding the functions of plant disease resistance proteins. Annu. Rev. Plant Biol. 2003, 54, 23-61. [CrossRef] [PubMed]

37. Cheng, Y.; Li, X.; Jiang, H.; Ma, W.; Miao, W.; Yamada, T.; Zhang, M. Systematic analysis and comparison of nucleotide-binding site disease resistance genes in maize. FEBS J. 2012, 279, 2431-2443. [CrossRef] [PubMed]

38. Jupe, F.; Pritchard, L.; Etherington, G.J.; MacKenzie, K.; Cock, P.J.A.; Wright, F.; Sharma, S.K.; Bolser, D.; Bryan, G.J.; Jones, J.D.G.; et al. Identification and localisation of the NB-LRR gene family within the potato genome. BMC Genom. 2012, 13, 1-14. [CrossRef]

39. Kang, Y.J.; Kim, K.H.; Shim, S.; Yoon, M.Y.; Sun, S.; Kim, M.Y.; Van, K.; Lee, S.H. Genome-wide mapping of NBS-LRR genes and their association with disease resistance in soybean. BMC Plant Biol. 2012, 12, 139. [CrossRef]

40. Whitham, S.; Dinesh-Kumar, S.P.; Choi, D.; Hehl, R.; Corr, C.; Baker, B. The product of the tobacco mosaic virus resistance gene N: Similarity to toll and the interleukin-1 receptor. Cell 1994, 78, 1101-1115. [CrossRef]

41. Wang, C.; Yang, Y.; Yuan, X.; Xu, Q.; Feng, Y.; Yu, H.; Wang, Y.; Wei, X. Genome-wide association study of blast resistance in indica rice. BMC Plant Biol. 2014, 14, 1-11. [CrossRef] [PubMed]

42. Arya, P.; Kumar, G.; Acharya, V.; Singh, A.K. Genome-wide identification and expression analysis of nbs-encoding genes in Malus X domestica and expansion of nbs genes family in rosaceae. PLoS ONE 2014, 9, 502. [CrossRef] [PubMed]

43. Afrin, K.S.; Rahim, M.A.; Park, J.I.; Natarajan, S.; Kim, H.T.; Nou, I.S. Identification of NBS-encoding genes linked to black rot resistance in cabbage (Brassica oleracea var. capitata). Mol. Biol. Rep. 2018, 45, 773-785. [CrossRef] [PubMed]

44. Gusmini, G.; Song, R.; Wehner, T.C. New sources of resistance to gummy stem blight in watermelon. Crop Sci. 2005, 45, 582-588. [CrossRef]

45. Lv, P.; Li, N.; Liu, H.; Gu, H.; Zhao, W.E. Changes in carotenoid profiles and in the expression pattern of the genes in carotenoid metabolisms during fruit development and ripening in four watermelon cultivars. Food Chem. 2015, 174, 52-59. [CrossRef] [PubMed] 